\title{
IMPACT OF FOREX MOVEMENT ON FOREIGN INSTITUTIONAL INVESTMENTS IN INDIA
}

*Prof. P K Mishra

\section{ABSTRACT}

Since early 1990s foreign institutional investors have been playing a significant role in Indian financial market. Thus, they are expected to be influenced by the foreign exchange rate movements. Thus, this paper is an attempt to study the impact of foreign exchange rate movements on foreign institutional investments. Using the correlation and regression analyses, it is observed that the relationship were negcitive thereby implying that FII is not governed by foreign exchange movement. However, the investigation of the nature and trend of foreign institutional investments reveal that such flows have the ability to affect the sources of funds in Indian capital market, strengthen the liquidity system, improve the efficiency of the company and motivate the Indian companies to adopt modern financial techniques and international best practices. Thus, the role of FIIs in developing Indian market cannot be ignored.

Keywords : India, FIIs, Forex Rate, Domestic Stress, Cross-border Contagion

\section{INTRODUCTION}

Indian financial market is one of the oldest across the globe and is the fastest growing and best among all the financial markets of the emerging economies. The equity market capitalization of the companies listed on the Bombay Stock Exchange, Mumbai (BSE) was US\$1.63 trillion as of December 2010, making it the 4th largest stock exchange in Asia and the 8th largest in the world. The BSE has the largest number of listed companies in the world. It has also been cited as one of the world's best performing stock market. As of December 2010, there are over 5,034 listed Indian companies and over 7,700 scrips on the stock exchange and thus, the Bombay Stock Exchange has a significant trading volume.
National Stock Exchange (NSE) is the third largest Stock Exchange in the world in terms of the number of trades in equities. It is the second fastest growing stock exchange in the world with a recorded growth of $16.6 \%$.

With the trade liberalization of early 1990s, the process of liberalization of capital flows came into being and thus, the Foreign Institutional Investment framework was setup and further rationalized by late 1990 s. Ever since the opening of the Indian equity market to foreigners, Foreign Institutional Investors (FIIs) investments have steadily grown from about Rs. 2,600 crores in 1993 to over Rs. $1,40,059$ crores in November 2010. Their share in total portfolio inflows to India grew to $\$ 32,797$ million in 2010 . In tandem

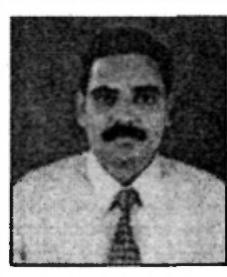

\section{*Prof. P K Mishra}

Assistant Professor in Economics

Central University of Jharkhand

Brambe, Ranchi 
with the boom in stock markets and sound global scenario, investments by FIIs in India were quite high in last few years, particularly since 2003-04. FIIs made a record investment in the Indian equity market in 2009, surpassing the 2007 inflows.

While it is generally held that portfolio flows benefit the economies of recipient countries, policy-makers worldwide have been more than a little uneasy about such investments. Portfolio flows, often referred to as 'hot money' are notoriously volatile compared to other forms of capital flows. Investors are known to pull back portfolio investments at the slightest hint of trouble in the host country often leading to disastrous consequences to its economy.

India's foreign investment framework has been influenced by perceptions that foreign investment is volatile and could respond sharply to adverse domestic events, thus aggravating a domestic crisis. They have been blamed for making large and concerted withdrawals thus, giving early signs of weakness. They have been held responsible for spreading financial crises causing 'contagion' in international financial markets.

Since the time FIIs were allowed to invest in Indian markets, their participation has increased except in 1998-99 and 2008-09. The gross purchases of debt and equity by FIIs increased by 37.7 percent, i.e., Rs.8,46,438 crore in 2009-10 from Rs.6,14,579 crores in 2008-09. The combined gross sales by FIIs increased by 6.6 percent, i.e., Rs 7,03,780 crores from Rs .6,60,389 crores during the same period in previous year. The total net inflow of FIIs was Rs.1,42,658 crore in 2009-10 as against an outflow of FIIs was Rs.45,811 crore in 2008-09. This was the highest net inflow for any financial year so far.
FIIs withdrew huge amounts in times of Global Financial Crisis from Indian capital market. From being net investors in 2007-08, investing a sum of Rs. 62,584 crore, they became net sellers in 2008-09. The financial year 2009-10 saw FIIs becoming net investors, investing a total of Rs 1,10,220 crores in Indian equity market. Month-wise the net FII was highest in equity segment in May 2009 (Rs 20,017 crore) followed by March 2010 (Rs.19,928 crore) and September 2009(Rs.18,344 crore). Indian capital market saw FIIs becoming net sellers only in one month, i.e., January, 2010.

Fig. 1: Trends in Foreign Institutional Investment

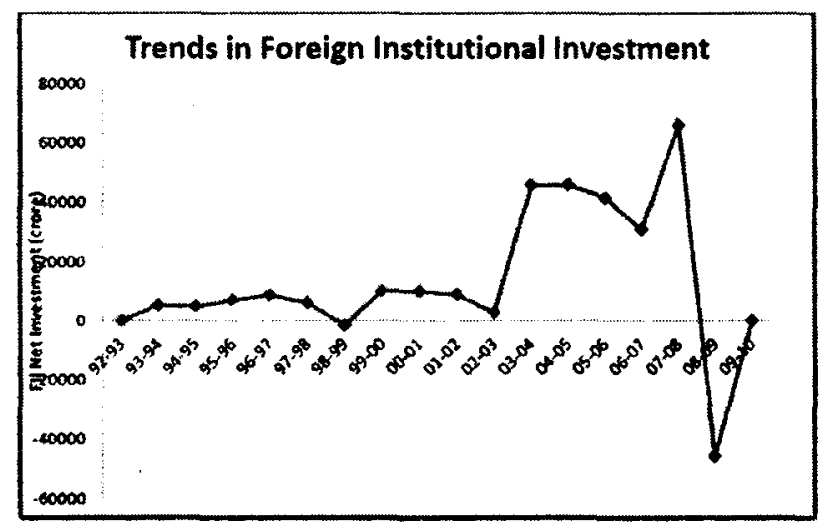

Source : SEBI

These inflows can be attributed to the quick recovery, post Lehman Brothers' bankruptcy, in the capital market of India. Significantly, by December 31, 2009, FIIs' net investment in the domestic bourses had touched a record Rs 80,500 crore, the highest ever inflow in rupee terms in a single year. This reflects the confidence that the investors had in the India's growth. The total investment made by FIIs in the domestic equity market in the April-December period of 2009 stood at Rs 89,576 crore. These fund houses had pulled out a net Rs 41,555 crore from Indian stocks in April-December period of 2008-09. 
Table-1 : FII Flows During Domestic Stress

\begin{tabular}{|l|c|c|c|c|c|c|}
\hline \multirow{2}{*}{ Events } & \multicolumn{4}{|c|}{ Net FII Flows (Rs.Crores) } & \multicolumn{3}{c|}{ Percentage to Market Capitalization } \\
\cline { 2 - 7 } & $\mathbf{T}-1$ & $\mathbf{T}$ & $\mathbf{T}+1$ & $\mathbf{T}-1$ & $\mathbf{T}$ & $\mathbf{T}+1$ \\
\hline $\begin{array}{l}\text { Parliament Attack } \\
\text { 12 Dec 2001 }\end{array}$ & -91.0 & 78.8 & -90.4 & -0.015 & 0.012 & -0.015 \\
\hline $\begin{array}{l}\text { Gujarat Riots } \\
\text { 27 Feb 2002 }\end{array}$ & 141.8 & 178.8 & -2.9 & 0.020 & -0.025 & -0.001 \\
\hline $\begin{array}{l}\text { Formation of UPA Govt. } \\
\text { 13 May 2004 }\end{array}$ & -295.1 & -604.4 & -504.4 & -0.029 & -0.060 & -0.050 \\
\hline $\begin{array}{l}\text { Mumbai Attacks } \\
\text { 26 Nov 2008 }\end{array}$ & -436.0 & Holiday & 419.4 & -0.015 & NA & 0.015 \\
\hline
\end{tabular}

Source: FII Working Group Report, MoF , Govt. of India

FIIs are believed to cause volatility in Indian Stock Market. One of the major impulse behind India's reluctant capital account liberalisation is a fear of an enmasse exit by foreign investors from the Indian economy. Thus, the most important issue now to examine is if FIIs exit en masse at times of domestic stress. The Table-1 shows information about net FII flows during the recent times of domestic stress.

In each of the above cited events of domestic stress, relatively small values are seen for the net sales by FIIs. Formation of UPA government saw largest values involving net sales of 0.11 percent of market capitalization on the event date $(T)$ and the following day $(T+1)$ associated with the formation of the UPA government in 2004. It can thus, be said that the scenario of massive sales by foreigners when India is experiencing difficulties does not fit the evidence examined here.

Another major event from which the insights into the en masse exit by FII can be obtained is the disclosure of the corporate governance fraud by Satyam Computer Services in December 2008. The investors did not appear to generalize from these events to India at large. There was no large scale exit. However, reallocation to other software companies was seen while maintaining the industry weights of the overall portfolio.

\section{Table-2 : FII Activities during Lehman Crisis}

\begin{tabular}{|c|c|c|c|}
\hline Months of 2008 & $\begin{array}{c}\text { Goss Buying } \\
\text { (Rs. Crores) }\end{array}$ & $\begin{array}{c}\text { Gross Selling } \\
\text { (Rs. Crores) }\end{array}$ & $\begin{array}{c}\text { Net Buying } \\
\text { (Rs. Crores) }\end{array}$ \\
\hline July & 70,592 & 68,010 & 2,582 \\
\hline August & 48,914 & 49,792 & -877 \\
\hline September & 75,214 & 80,061 & $-4,846$ \\
\hline October & 52,014 & 68,310 & $-16,296$ \\
\hline November & 37,746 & 36,383 & 1,363 \\
\hline December & 38,925 & 36,979 & 1,945 \\
\hline
\end{tabular}

Source: $S E B I$

While investigating about the events that could have led to the en masse exit of FIIs, one cannot forget to mention the Lehman Crisis. The table below displays the data for FII activity during the crisis. The biggest exit in this data was in October 2008 , of Rs.16,296 crores of equity capital.
However, in October 2008 FIIs (as a whole) purchased Rs.52,104 crores of shares and sold Rs.68,310 crores.

Taking into consideration the macro economic issues, the currency exposures of the firms now can be addressed. Different theories on 
currency exposures of the firms exist. One view involves thinking that India is mostly closed and that firms are relatively unsophisticated about addressing exchange rate risk. An alternative view involves thinking that India is substantially open, and that the firms are quite concerned about exchange rate risk. The Table-3 shows the analysis of how currency exposure of large Indian firms varied across changes in exchange rate regime.
Fig.2: FII Activities during Lehman Crisis

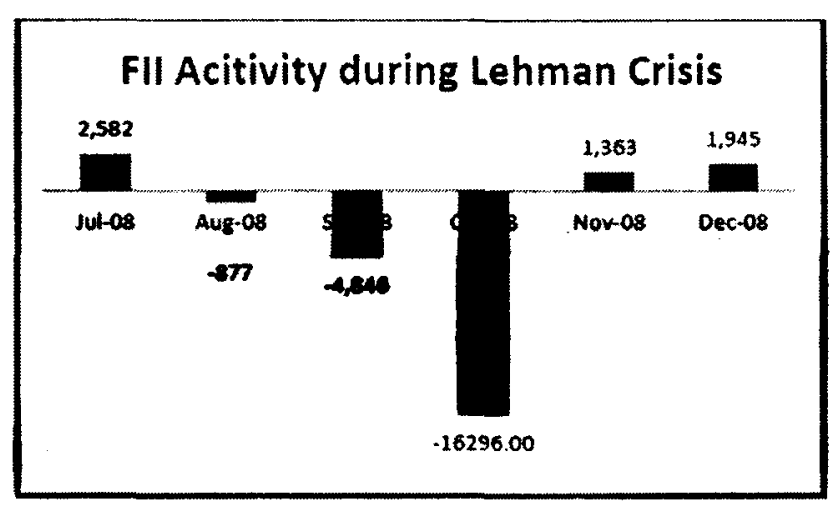

Table-3: Currency Exposure of Large Indian Firms

\begin{tabular}{|l|c|c|}
\hline \multicolumn{1}{|c|}{ Period } & INR/USDVolatility & Average Currency Risk of the Firm \\
\hline 1 April 1993 - 17 Feb 1995 & 0.16 & 5.889 \\
\hline 17 Feb 1995 - 21 Aug 1998 & 0.93 & 0.540 \\
\hline 21 Aug 1998 - 19 March 2004 & 0.29 & 3.753 \\
\hline 19 March 2004 to 31 March 2008 & 0.64 & 2.066 \\
\hline
\end{tabular}

The table- 3 suggests that when the central bank has an exchange rate regime with reduced exchange rate flexibility, and a country's capital account is sufficiently open, firms are alert and able to 'modify their currency risk to exploit opportunities presented to these firms. Indian multinationals handling of currency risk patterns then suggest relative agility in managing changes in the exchange rate.

It is with this backdrop this paper is an attempt to examine the impact of foreign exchange movements on foreign institutional investments in India. The rest of the paper is organised as follows: Section 2 reviews the existing literature on the issue; Section 3 discusses the data and methodology of the study; Section 4 makes the analysis; and Section 5 concludes.

\section{LITERATURE REVIEW}

The issue of the impact of foreign exchange movements on foreign institutional investments has been addressed by few economists and financial analysts. Ajaysingh and Keyur (2008)measured the relationship between exchange rate, FII and stock index. The period used for the analysis is from January 2000 to December, 2005. Simple correlation and regression analysis were used and it was found that no long run positive correlation exists between exchange rate and Stock Index except for year 2002 and 2005. FII and Stock Index show positive correlation, but fail to predict the future value.

Chakraborty (2007) investigated whether foreign institutional investment flows affect or are affected by domestic stock market returns. With the application of various stochastic tools such as Granger causality test she found that FII flows are more an effect than a cause of the stock market returns in India.

Pal (2006) examined the impact of Foreign Portfolio Investment on India's economy and industry. The findings of this paper show that the 
perceived benefits of foreign portfolio investment have not been realized in India. The study found that the entry of foreign portfolio investors will boost a country's stock market and consequently the economy, does not seem be working in India. The influx of FIIs has indeed influenced the secondary market segment of the Indian stock market. But the supposed linkage effects with the real economy have not worked in the way the mainstream model predicts. Instead there has been an increased uncertainty and scepticism about the stock market in this country. On the other hand, the surge in foreign portfolio investment in the Indian economy has introduced some serious problems of macroeconomic management for the policymakers. Uncertainty and volatility associated with FPI have not only reduced the degrees of manoeuvrability available to the policymakers but have also forced them to take some measures which impose significant fiscal cost on the economy.

Chakrabarti (2001) analyzed these flows and their relationship with other economic variables and found that while the flows are highly correlated with equity returns in India, they are more likely to be the effect than the cause of these returns; the FIIs do not seem to be at an informational disadvantage in India compared to the local investors; the Asian Crisis marked a regime shift in the determinants of FII flows to India with the domestic equity returns becoming the sole driver of these flows since the crisis.

Bhattacharya (2001) examined the cause and effect relationship between the stock prices and macroeconomic aggregates in the foreign sector in India. The causal relationship between BSE sensitive index and other three variables, viz., exchange rate, foreign exchange reserves and value of trade balance using monthly data for the period 1990-91 to 2000-01 was established by applying the techniques of unit-root tests, cointegration and the long-run Granger non-causality test proposed by Toda and Yamamoto (1995). They concluded that no causal relationship exists between stock prices and three variables considered.

Nathand Samanta(2003) examined causal relationship between the returns in the stock market and Forex market in India, using daily data from March 1993 to January 2002. They concluded that a weak causal link exists between the two, though, in recent years, there has been a strong causal influence from stock market return to forex market return. The authors, while giving explanations for the existence of relationship, cited portfolio balance approach as alternative explanation. They said that blooming stock market attracts capital flows from foreign investors, which may cause an increase in the demand for a country's currency leading to appreciation of local currency. The reverse happens in case of falling stock prices where the investors try to sell their stocks to avoid further losses and convert their money into foreign currency to move out of the country leading to increasing demand for foreign currency resulting in depreciation of local currency. Moreover, foreign investment in domestic equities could increase over time due to benefits of international diversification that foreign investors would gain. Furthermore, movements in stock prices may influence exchange rates and money demand because investors'wealth and liquidity demand could depend on the performance of the stock market.

Kumar (2009) examined dynamic relation between stock index and exchange rate by using the daily data for India. The long run relationship between the two variables is tested with the help of unit root and cointegration tests. To examine the dynamic relationship between the variables, the study also uses linear and nonlinear granger causality tests after removing the volatility dependence from the series. The nonlinear 
granger causality between stock index and exchange rate was investigated by using bi-variate noisy Mackey Glass model. The empirical evidence suggested that there is no long-run relationship; however, there is bidirectional linear and nonlinear granger causality between stock index and exchange rates. The findings of the study strongly support the micro and macroeconomic approach on the relationship between exchange rates and stock prices.

Reddy and Sebastin (2008)made an attempt to study the interaction between the stock and the forex markets in India by computing transfer entropy between daily data series of the 5- stock index of NSE, viz., Nifty and the exchange rate of Indian Rupee vis-à-vis US Dollar, viz., Reserve Bank of India reference rate. They divided the entire period-November 1995 to March 2007 - selected for the study, into three subperiods for the purpose of analysis, considering the developments that took place during these sub-periods. They found that only low levels of interactions between the stock market and the forex market of India exist. Also, they found that the flow from the stock market to the forex market is more pronounced than the flow in the reverse direction.

Mishra, Swain and Malhotra (2007) provided a useful insights into how information is transmitted from stock market to foreign exchange market and vice versa. This paper explored volatility spillover between the Indian stock and foreign exchange markets. The results indicate that there exists a bidirectional volatility spillover between the Indian stock market and the foreign exchange market with the exception of S\&P CNX NIFTY and S\&P CNX 500. The findings of the study also suggest that both the markets move in tandem with each other and there is a long run relationship between these two markets. The results of significant bidirectional volatility spillover suggest that there is an information flow (transmission) between these two markets and both these markets are integrated with each other.

Naeemand Rashid (2002)examined whether stock prices and exchange rates are related to each other or not. Both the long-run and the short-run association between these variables are explored by the authors. The study uses monthly data on four South Asian countries, including Pakistan, India, Bangladesh and Sri- Lanka, for the period January 1994 to December 2000. Tools such as cointegration, vector error correction modelling technique and standard Granger causality tests were employed to examine the long-run and shortrun association between stock prices and exchange rates. The results of this study show no short-run association between the said variables for all four countries. There is no long-run relationship between stock prices and exchange rates for Pakistan and India as well. However, for Bangladesh and Sri Lanka there appear to be a bidirectional causality between these two financial variables.

Rai and Bhanumurthy (2004) examined the impact of huge volumes of FII flow on the domestic markets. They analyzed monthly data and found that FII inflow depends on stock market returns, inflation rates and ex-ante risk. In terms of magnitude, the impact of stock market returns and the ex-ante risk turned out to be the major determinants of FII inflow. However, the study did not find any causative link running from FII inflow to stock returns. Stabilizing stock market volatility and minimizing the ex-ante risk would help to attract more FII, an inflow of which has positive impact on the real economy.

- It is thus inferred that the extant literature is very thin concerning the studies examining the impact of foreign exchange movements on foreign institutional investment flows. Therefore, this paper is an attempt to fill this gap in the literature. 


\section{DATA AND METHODOLOGY}

The very objective of this paper is to study the impact of foreign exchange movements on foreign institutional investment flows in India. Also, emphasis has been laid on understanding of the behaviour of Foreign Institutional Investors in India in terms of various macroeconomic and microeconomic events. This study, thus gives an insight on the relationship between the foreign exchange movement and foreign institutional investment flows. The study shall be beneficial to the investors in the sense that it provides them with the detail mechanism about the manner in which FIIs affect Indian Stock Market and the manner in which it is influenced by exchange rate movements. The sample of the study spans from 2001 to 2010. The study uses monthly data. All necessary data have been obtained from the publications of RBI and SEBI. So far as the methodology of the study is concerned, the impact of foreign exchange movement is studied on FIIs by establishing correlation and regression between the two variables - Net Purchases by FIIs and Forex Rate.

\section{RESULTSAND DISCUSSION}

The impact of forex movement on foreign institutional investment flows in India has been observed over 10-year data of monthly exchange rate movement and monthly FII net purchases by establishing correlation and regression between them.

\section{Correlation Analysis}

The Pearson's correlation coefficient has been calculated and the significance has been tested by formulating the following hypotheses.

$\mathrm{H} 0=$ No significant relation exists between net FII purchases and foreign Exchange rate

$\mathrm{H} 1$ = Significant correlation exists between net FII purchases and foreign Exchange rate

Table-4: Pearson's Correlation Coefficients

\begin{tabular}{|c|l|c|c|}
\hline Variables & & Net FII Purchases & Forex Rate \\
\hline \multirow{4}{*}{ Net FII Purchases } & Pearson's Correlation & 1 & -0.068 \\
& Sig. (2 tailed) & - & 0.442 \\
& N & 132 & 132 \\
\hline \multirow{3}{*}{ Forex Rate } & Pearson's Correlation & -0.068 & 1 \\
& Sig. (2 tailed) & 0.442 & - \\
& N & 132 & 132 \\
\hline
\end{tabular}

The Pearson's correlation between Net FII Purchases and Exchange Rate movement comes out to be -0.068 . The figure indicates that a low degree and negative linear association exists between the variables. The correlation coefficient found is insignificant (since $\mathrm{p}=0.442$ ). Thus, the null hypothesis is accepted and it is said that there exists no correlation between the variables.

\section{Regression Analysis}

Now, the dependency of net FII purchases on forex movements can be observed by estimating a linear regression model and testing the following hypotheses.

$\mathrm{H} 0=$ No significant dependency of net FII purchases on forex rate movements exits

$\mathrm{H} 1=$ Net FII purchases are dependent on forex rate movements 


\begin{tabular}{|l|c|c|c|}
\hline $\mathbf{R}$ & R-square & Adjusted R-square & Std. Error of the Estimate \\
\hline 0.068 & 0.005 & -0.003 & 6726.67 \\
\hline
\end{tabular}

ANOVA $^{b}$

\begin{tabular}{|c|c|c|c|c|c|}
\hline Model & Sum of squares & Degrees of freedom & Mean square & F & Sig. \\
\hline Regression & $2.693 \mathrm{E} 7$ & 1 & $2.693 \mathrm{E} 7$ & 0.595 & $0.442^{\mathrm{a}}$ \\
\hline Residual & $5.882 \mathrm{E} 9$ & 130 & $4.525 \mathrm{E} 7$ & & \\
\hline Total & $5.909 \mathrm{E} 9$ & 131 & & & \\
\hline
\end{tabular}

a: Predictors : (Constant), Forex Rate

b: Dependent Variable: Net FII Purchases or sales

It is required to test whether the regression is significant or not. This is found with the help of ANOVA. The sig. comes out to be 0.442 , which implies that the regression is insignificant. Thus, we can say that significant proportion of variability in FII cannot be accounted by variability in exchange rate movement. Hence, the amount that foreign investors invest in India is not governed by exchange rate movement.

\section{CONCLUSION}

Indian equity market saw huge inflows from Foreign Institutional Investors over the recent years. The SENSEX touched the 20,000 level and NIFTY crossed 6150 level in October 2010 due to huge foreign inflow. FIIs invested more than Rs 27,500 crores in Indian equity market since 6 th September, 2010 till 30th September 2010. However recently, they withdrew a lot of amount from the market. The total number of FIIs registered with the Securities and Exchange Board of India (SEBI) dropped in past four months to 1,702 as on March 1, 2011 against 1,741 FIIs as on October 29, 2010. The number is lower even when compared with 1,713 FIIs registered as on March 31, 2010. Such fluctuations in FIIs investment saw the Indian stock market touching the benchmark levels at one point of time and dwindling down to the lows, the other point of time. The paper investigated the impact of foreign exchange movement on FII in India. The results obtained for the relationship were negative thereby implying that FII is not governed by foreign exchange movement. However, the investigation of the nature and trend of foreign institutional investments reveal that such flows have the ability to affect the sources of funds in Indian capital market, strengthen the liquidity system, improve the efficiency of the company, and motivate the Indian companies to adopt modern financial techniques and international best practices. Thus, the role of FIIs in developing Indian market cannot be ignored.

India, being a capital scarce country needs huge foreign investments for the development of the country. However, the easy exit route brings an element of uncertainty in these types of inflows. Thus, Indian policy makers should adopt policies that should, on the one hand, attract more foreign institutional investments in India with being more cautious, on the other side of the coin. The policy makers should relax the foreign capital policies by bringing built-in-cushion within the system that would weaken the destabilizing effect of sudden reversals. 


\section{References}

- Bhattacharya, Basabi and Mukherjee, Jaydeep (2001): "C'ausal Relationship between Stock Market and Exchange rate, Foreign Exchange Reserves and Value of Trade Balance: A Case Study for India", Akron Business and Economic Review, Vol.12, pp.7-12

- Chakrabarti, Rajesh (2001): "FII flows to India: Nature and Causes", Money and Finance, Vol.2, Issue 7.

- Chakraborty, Tanupa (2007): Foreign Institutional Investors Flows and Indian Stock Market Returns-A Cause and Effect Relationship Study, Indian Accounting Review, Vol. 11, No. 1, pp 35-48.

- Kumar, Manish (2009): A Bivariate Linear and Non-linear Causality between Stock prices and Exchange Rates, Economics Bulletin, Vol. 29, No. 4, pp.2884-2895.

- Mishra, Alok Kumar, Swain, Niranjan and Malhotra, D.K., 2007. "Volatility Spillover between Stock and Foreign Exchange Markets: Indian Evidence", International Journal of Business, Vol.12, No.3, pp.343359.

- Naeem Muhammad and Abdul Rashid, (2002): "Stock Prices and Exchange Rates: Are they Related? Evidence from South Asian Countries", The Pakistan Development Review, Volume 41, Number 4, Pages 535550.
- Nath, Golak C. and G.P. Samantha, (2003): "Dynamic Relation between Exchange Rate and Stock Prices-A Case for India," NSE News, National Stock Exchange of India Limited (NSEIL), February 2003, pp.15-18.

- Parthapratim, Pal (2006): Foreign Portfolio Investment, Stock Market and Economic Development: A Case Study of India, Annual Conference on Development and Change Mission: Promoting Development in a Globalized world, Brazil, November 18-20, pp. 1-24

- Rajput, Ajay Singh, and Thaker, Keyur (2008): "Exchange Rate, FII and Stock Index Relationship in India, Vilakshan, XIMB Journal of Management, March, pp. 43-56.

- Rai, Kulwant and Bhanumurthy, N. (2004): "Determinants of FII in India: The role of Return, Risk and Inflation", The Developing Economies, XLII-4, pp 479-93.

- Reddy Y. and Sebastin A. (2008): Interaction between Forex and Stock market in India: An Entropy Approach, Vikalpa, Vol.33, No.4, pp. $27-45$

- Toda, H.Y., Yamamoto, T. (1995): "Statistical Inference in Vector Autoregressions with Possibly Integrated Processes". Journal of Econometrics, 66, 225-250. 